\title{
低分子量 Heparin（FR-860）の家鬼における抗血栓作用
}

\author{
浜野修一郎, 小松 英忠, 池田 滋 \\ キッセイ薬品工業 (株) 中央研究所* \\ 桜 川信 男 \\ 富山医科薬科大学検查部** \\ (1989年 7 月 7 日 [特])
}

\begin{abstract}
要約 : 低分子量 heparin (FR-860) の抗血栓作用を家鬼動静脈シャントモデルおよび in vitro の系にて通 常 heparin と比較した. 動静脈シャントモデルに执いて血流開始30分後の血栓重量は FR-860 (12.5 $50 \mathrm{U} / \mathrm{kg}$ ) 投与により用量依存的に抑制された。 また，通常 heparin 投与でもほ注同等の抑制が認めら れた. 血流開始 5 分後の抗ファクターXa (F.Xa) 活性も, FR-860 および通常 heparin は共にほぼ同 等の值を示し, 血栓重量との間に有意な負の相関が認められた。一方, FR-860 は通常 heparin に比較 して活性化部分トロンボプラスチン時間 (aPTT), プロトロンビン時間 (PT) およびトロンビン時間の 延長作用は弱かった. 同様に, in vitro 飞捻いても FR-860 は通常 heparin とほぼ同等の抗 F.Xa 活 性を示したが, カルンウム再加時間, aPTT, PT の延長作用および抗トロンビン活性は通常 heparin 飞 比し軽度であった．また, ex vivo において FR-860 および通常 heparin は血小板凝集に影響を及ぼさ なかった. FR-860 は通常 heparin とほぼ同等の抗 F.Xa 活性に依存した抗血栓作用を有し, 出血因子 である抗トロンビン活性が弱いことにより, 安全かつ有効な抗血栓薬と考えられる.
\end{abstract}

緒言

一般的に透析括よび静脈血栓などの抗㠜固剤として通 常 heparin が使用されるが, 出血傾向などの副作用が 報告されている1 3). 通常 heparin は平均分子量 10,000 $\sim 15,000$ の硫酸多糖類である ${ }^{4)}$ が, 最近ほぼ同等の抗 アクター Xa（F.Xa) 活性を持つにもかかわらず, 活 性化部分トロンボプラスチン時間（aPTT）の延長作用 は弱く, そのため出血などの副作用の軽減が期待される 低分子量 heparin が報告された ${ }^{5 \sim 7)}$. しかしながら, 透 析モデルに怙ける低分子量 heparin の効果を検討した 報告は少ない。

本研究では, 透析モデルの一つとして家鬼動静脈シャ ントモデルを考案し，それに及ぼす効果を低分子量 heparin (FR-860) と通常 heparin について比較検討 した.

\section{実 験 材 料}

\section{1. 使用薬物}

FR-860 (KabiVitrum) は通常 heparin を亜硝酸分

\footnotetext{
* 函399 松本市芳野19-48

** 昰930-01 富山市杉谷2630
}

解することにより得られた平均分子量 $4,000 〜 6,000$ の白 色〜淡黄色の粉末または粒で, においはなく, 水に溶け やすい.

また，その他本研究には heparin (小玉), urethane (Sigma), sodium citrate (和光純薬), calcium chloride $\left(\mathrm{GaCl}_{2}\right.$, 半井化学), Actin (ミドリ十字), Thromboplastin・ $C^{\circledast}$ (ミドリ十字), テストチーム『「人 パリン」(第一化学), S-2222 (第一化学), S-2238 (第 一化学), adenosine 5'-diphosphate (ADP, Sigma), collagen（二光バイオサイエンス）を使用した．被験薬 物は生理食塩液に溶解し, その濃度は抗 F.Xa 活性 （U）で表示した.

\section{2. 実験動物}

体重 $3 \mathrm{~kg}$ 前後の雄性日本白色家鬼（ケアリー）を使 用した.

\section{実 験 方 法}

\section{1. 動静脈シャントモデル}

家鬼を urethane 麻醉 $(1.2 \mathrm{~g} / \mathrm{kg}$, i.p.) し, 以下飞述 ベるごとくの動静脈シャントモデルを考案した． 右大腿 動脈および大腿静脈にそれぞれ留置針 $(20 \mathrm{G}$, テルモ) を挿入し，その留置針に 約 $20 \mathrm{~cm}$ のポリエチレンチニ ーブ (内径 : $3.2 \mathrm{~mm}$, 文京医理硝製作所) を接続した. 
血流再開30分後に血流を停止し, チューブ内を生理食塩 液 $10 \mathrm{ml}$ で洗浄した. チューブを取りはずし，その内 側に付着した血栓の重量を秤量した。.また, 血流開始 5 分後に大腿動脈から $3.8 \%$ sodium citrate $1 / 10$ 容量で 採血し凝固機能を測定した. 薬物は血流開始直前にチュ ーブ内に投与した.

\section{2. in vitro における凝固系}

家鬼頸動脈より $3.8 \%$ sodium citrate $1 / 10$ 容量で 採血し， $2,000 \times \mathrm{g}$ で 15 分間の遠心分離後血漿を調製し た. 血漿に被験薬物を添加し, 各凝固機能を測定した。

\section{3. 凝固機能検查}

1）血漿中抗 F.Xa 活性

血漿中抗 F.Xa 活性の測定には, テストチーム「へ パリン」キットを使用した.

2) カルシウム再加時間

血漿 $200 \mu 1$ に $25 \mathrm{mM} \mathrm{CaCl}_{2}$ を $200 \mu 1$ 添加し, $37^{\circ} \mathrm{C}$ でフィブリン塊析出までの時間を計測した.

\section{3) аРTT}

血漿 $100 \mu \mathrm{l}$ に Actin $100 \mu \mathrm{l}$ 添加し, $37^{\circ} \mathrm{C}$ で2分間 放置後 $20 \mathrm{mM} \mathrm{CaCl} 2$ を $100 \mu \mathrm{l}$ 添加し, フィブリン塊 析出までの時間を計測した.

\section{4) プロトロンビン時間 (PT)}

血漿 $100 \mu \mathrm{l}$ に Thromboplastin・Cを $200 \mu \mathrm{l}$ 添加 し, $37^{\circ} \mathrm{C}$ でフィブリン塊析出までの時間を計測した.

\section{5）トロンビン時間}

血漿 $200 \mu 1$ に家鬼より精製したトロンビン8,9)(5 U/ $\mathrm{ml}$ )を $100 \mu \mathrm{l}$ 添加し, $37^{\circ} \mathrm{G}$ でフィブリン塊析出まで の時間を計測した.

6) 抗 F.Xa 活性执よび抗トロンビン活性

Tris-HCl 緩衝液 ( $\mathrm{pH}$ 8.4) $150 \mu \mathrm{l}$ 飞血漿 $45 \mu \mathrm{l}$ と終 濃度が $0.2 \sim 1 \mathrm{U} / \mathrm{ml}$ となるように調整した薬物 $5 \mu \mathrm{l}$ の混液を加兄, さらに精製家鬼 F.X $\mathrm{a}^{8,10)}$ または精製家 鬼トロンビンを $100 \mu 1$ 添加した. $37^{\circ} \mathrm{C}$ で30秒後に合成 基質 S-2222 または S-2238 $200 \mu 1$ 添加して， 5 分 後に F.Xa またはトロンビンの残存活性を $\mathrm{p}$-ニトロア ニリンの生成を指標として波長 $405 \mathrm{~nm}$ で測定した.

\section{4. 血小板凝集}

家鬼耳動脈より $3.8 \%$ sodium citrate $1 / 10$ 容量で採 血した後, 薬物を耳静脈より注入し，5分後に再び採血 した. その血液を $220 \times \mathrm{g}$ および $880 \times \mathrm{g}$ で10分間遠心 分離し多血小板血漿拉よびそ血小板血漿を調製した. ADP $(20 \mu \mathrm{M})$ 打よび collagen $(20 \mu \mathrm{g} / \mathrm{ml})$ による凝 集を血小板凝集装置 (PAT-4A, 二光バイオサイェンス) で測定した.

\section{5. 統計学的処理}

測定值は各群の平均値と標準誤差で表し, 有意差検定 は Student's $t$-test そより行なった.

\section{実 験 結 果}

\section{1. 動静脈シャントモデルに及ぼす影響}

家鬼動静脈シャントモデルに括いて血流開始15分後か ら血栓形成が開始し，30分後のチューブ内の血栓重量は $399 \pm 59.3 \mathrm{mg}$ となった. FR-860 (12.5 50 U/kg) は $25 \mathrm{U} / \mathrm{kg}$ 以上の投与で有意かつ用量依存的な抑制を示し た。また，通常 heparin は 25 打よび $50 \mathrm{U} / \mathrm{kg}$ 投与に

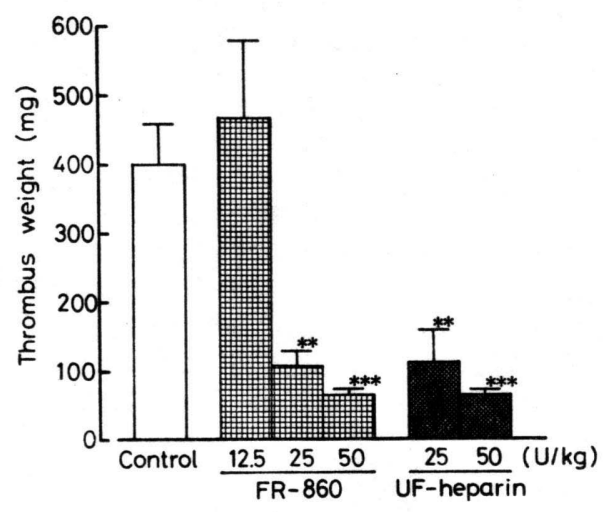

Fig. 1 Effect of FR-860 and unfractionated (UF)-heparin on thrombus weights in the ateriovenous shunt model of rabbits. Each column indicates the mean ( \pm S.E.) of $5 \sim 6$ rabbits. $* *$ and $* * *$, significant difference from the control at $\mathrm{P}<0.01$ and $\mathrm{P}<0.001$, respectively.

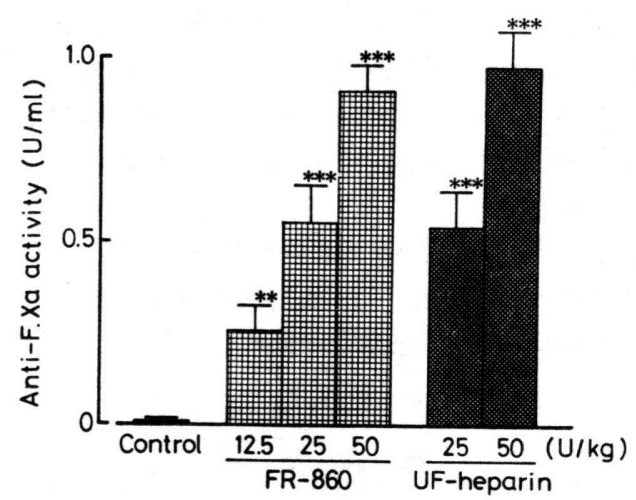

Fig. 2 Effect of FR-860 and unfractionated (UF)-heparin on the anti-F.Xa activity in the aterio-venous shunt model of rabbits. Each column indicates the mean ( \pm S.E.) of $5 \sim 6$ rabbits. $* *$ and $* * *$, significant difference from the control at $\mathrm{P}<0.01$ and $\mathrm{P}<0.001$, respectively. 
より FR-860 とほぼ同等な抑制作用を示した（図 1 ). 血流開始 5 分後の 血嶈中抗 F.Xa 活性を図 2 に示し た. FR-860 (12.5 50 U/kg) および通常 heparin（25 および $50 \mathrm{U} / \mathrm{kg}$ ）はほぼ同等かつ用量依存的な抗 F.Xa 活性を示した.

aPTT は対照群において 19.3 し，FR-860 および通常 heparin は用量に依存した延 長作用を示し，その作用は通常 heparin の方が強力で あった（図 3A). PT は対照群が7.8 0.15 秒であるの に対し，FR-860 $50 \mathrm{U} / \mathrm{kg}$ 投与群は $8.1 \pm 0.34$ 秒とほと んど影響を受けなかった. 一方, 通常 heparin $50 \mathrm{U} / \mathrm{kg}$ 投与群は9. $0 \pm 0.12$ 秒と有意な延長を示した（図 $3 B$ ). ト ロンビン時間は対照群では9.1土0.3秒であるのに対し, FR-860 群 (12.5〜50 U/kg) はトロンビン時間に統計 上の有意差は出たものの著明ではなかった. 一方, 通常 heparin（25 および $50 \mathrm{U} / \mathrm{kg}$ ）はトロンビン時間を用量 に依存して著明に延長した（図 3G).

\section{2. in vitro の凝固系に及ぼす影響}

家鬼血漿に終濃度が 0.2〜 $10 \mathrm{U} / \mathrm{ml}$ となるように薬物 を添加した際のカルシウム再加時間, $\mathrm{aPTT}$ およ゙ PT に及ぼす影響を図 4 に示した. カルシウム再加時間およ
び aPTT において FR-860 および通常 heparin は用量 に依存した延長作用を示し，通常 heparin の方がいず れの場合も強かった. PT に対して FR-860 は $10 \mathrm{U} / \mathrm{ml}$ までほとんど影響を及ぼさなかったが，通常 heparin は用量に依存した延長作用を示した.

FR-860 および通常 heparin はほぼ同等の抗 F.Xa 活性を示したが，抗トロンビン活性においては FR-860 に比し通常 heparin の方がより強力であった（図 5 ).

\section{3. ex vivo の血小板凝集に及ぼす影響}

FR-860 および通常 heparin $(50 \mathrm{U} / \mathrm{kg})$ は ADP 特 よび collagen 凝集に影響を及ぼさなかった.

\section{考察}

家鬼動静脈シャントモデルにおいて，FR-860 および 通常 heparin は血栓形成および F.Xa 活性をともに用 量依存的に抑制した. 一方, aPTT において FR-860 は通常 heparin に比較して軽度な延長作用を示したに すぎなかった. また，in vitro においても FR-860 は 通常 heparin に比較してほぽ同等の抗 F.Xa 活性を示 したが，抗トロンビン活性は軽度であった. Holmer $ら^{5,6)}$ は heparin の分子量が低下するのに従い, 抗
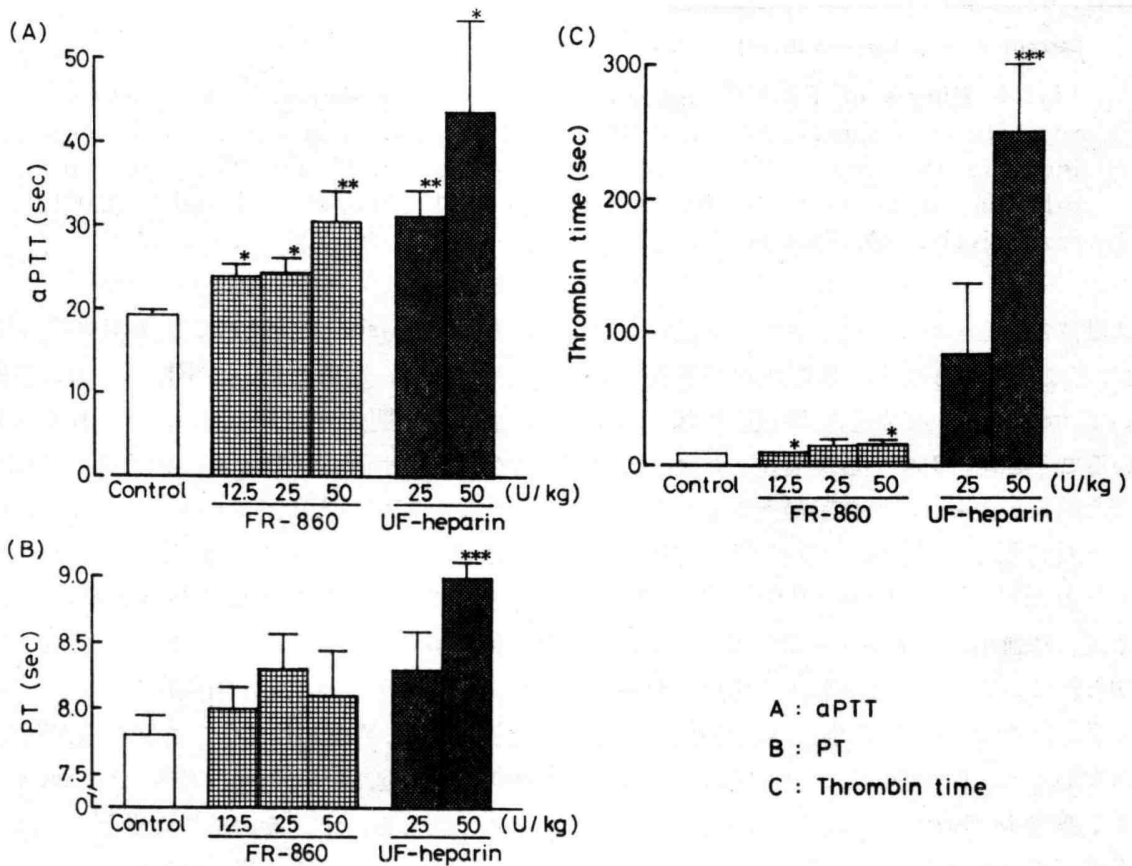
A : aPTT
B : PT
C : Thrombin time

Fig. 3 Effects of FR-860 and unfractionated (UF)-heparin on the aPTT, PT and thrombin time in the arterio-venous shunt model of rabbits. Each column indicates the mean ( \pm S.E.) of $5 \sim 6$ rabbits. $*$, $* *$ and $* * *$, significant difference from the control at $\mathrm{P}<0.05, \mathrm{P}<0.01$ and $\mathrm{P}<0.001$, respectively. 
(A)

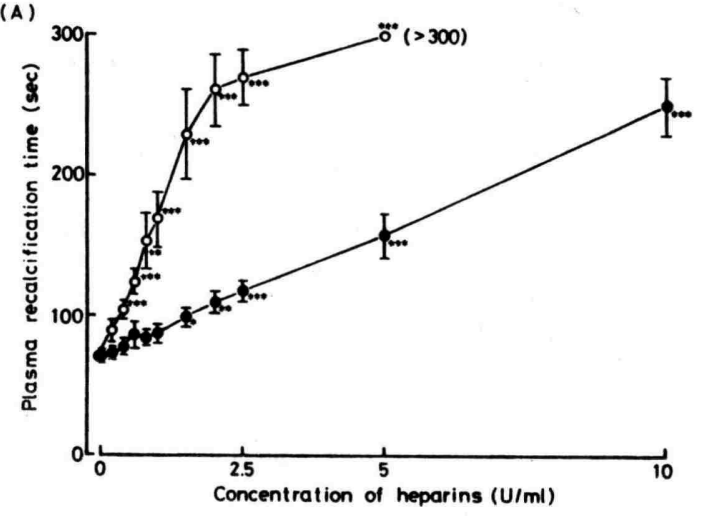

(B)

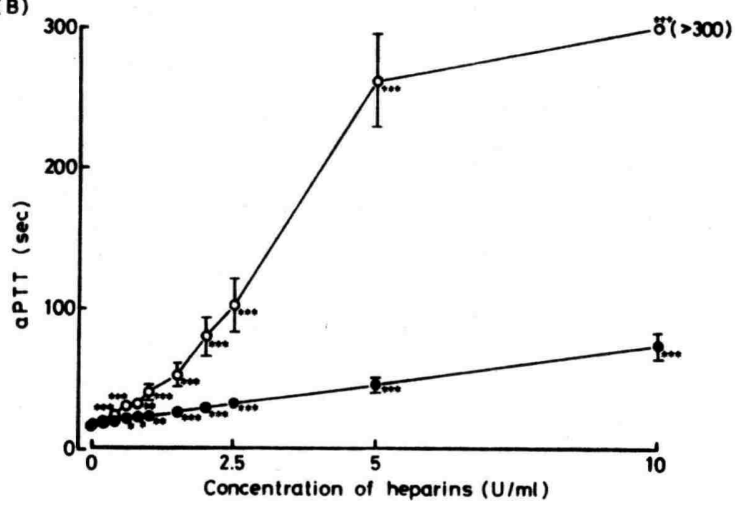

(C)

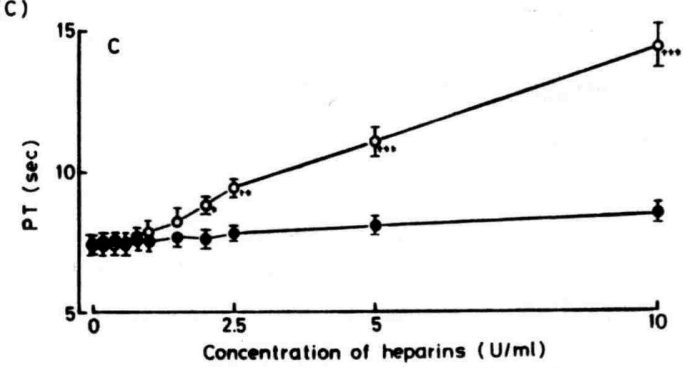

Fig. 4 Effects of FR-860 and unfractionated (UF)-heparin on the plasma recalcification time, aPTT and PT in rabbits plasma in vitro. Each point indicates the mean $( \pm$ S.E. $)$ of 5 experiments. $*, * *$ and $* * *$, significant difference from the level without drugs $(0)$ at $\mathrm{P}<0.05, \mathrm{P}<0.01$ and $\mathrm{P}<0.001$, respectively. $\odot$, FR-860; O, UF-heparin; $>300$, over 300 sec.

F.Xa 活性は維持されるものの, 抗トロンビン活性, 抗 F.IXa 活性などは低下すること, さらに家鬼静脈血栓 モデルに扔いて heparin の抗血栓作用は抗 F.Xa 活性 と相関していることを報告している．前述したように本 研究でも同様な結果が得られ，家鬼動静脈シャントモデ ルに拉いて抗血栓作用と抗 F.Xa 活性の間飞有意な負 の相関が 認められた（相関係数 $r=-0.691, \mathrm{P}<0.01$ ). また, 血栓形成には血小板も重要な役割を果たしている ことはよく知られている ${ }^{11,12)}$. 乙かし, 本研究において FR-860 拈よび通常 heparin の血小板への影響はほと んど認められなかった．以上のことより，本モデルでの FR-860 および通常 heparin の抗血栓作用には, F.Xa 活性に対する阻害作用が強く関与しているものと思われ る.

血栓形成において FR-860 と通常 heparin は注ぼ同 等の抑制作用を示したが，一般的に低分子量 heparin
は通常 heparin 飞比較して血中半減期が長いことが知 られている.臨床において FR-860 および通常 heparin の血中半減期は $40 \mathrm{U} / \mathrm{kg}$, i.v. でそれぞれ 126 分および 57 分と報告され ${ }^{13)}$, 我々もイ又透析モデルにおいて同様 の結果を得ている ${ }^{14)}$. しかし，家鬼では FR-860 およ び通常 heparin の血中半減期はそれぞれ 28分および 17 分と短く, FR-860 と通常 heparin の差が小さいとい う報告がある ${ }^{15)}$. 本モデルでは家鬼を用いていること， さらに血栓重量の測定は両薬物の半減期を超えた血流開 始 30 分後に行なわれていることを考光併せると，FR860 および通常 heparin の間には抗 F.Xa 活性におい て差は認められず，その結果両者ともにほぼ同等の抗血 栓作用を示したものと思われる.

また, 低分子量 heparin は通常 heparin 飞比較して 出血などの危険性が低いことが報告されている6 ${ }^{6,16)}$. 本研究に打いて FR-860 は通常 heparinに比較して 
(A)

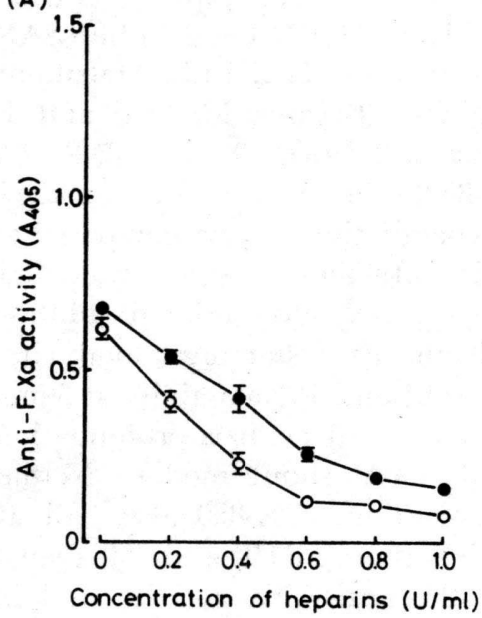

(B)

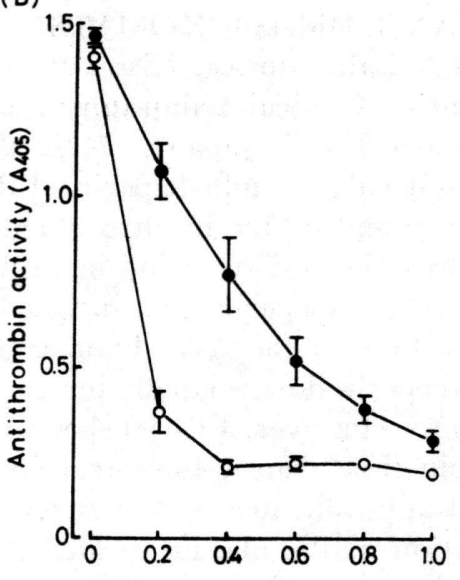

Concentration of heparins $(\mathrm{U} / \mathrm{ml})$

Fig. 5 Effects of FR-860 and unfractionated (UF)-heparin on the anti-F.Xa activity (A) and antithrombin activity (B) in rabbit plasma in vitro. Each value was expressed as the absorbance of p-nitroaniline at $405 \mathrm{~nm}$. Each point indicates the mean ( \pm S.E.) of 5 experiments. FR-860; O, UFheparin.

aPTT, PT およびトロンビン時間に及ぽす影響は弱か ったこと,さらに in vitro でも同様な傾向が認められ たことは，前述の報告 ${ }^{6,16)}$ を支持しているるのと考えら れる。 また，低分子量 heparin は通常 heparin に比較 してリポタンパクリパーゼの血中放出作用が弱く，脂質 代謝異常発現に伴う心臓などの循環器系に影響を及ぼす 可能性が低いという報告もある17,18).

以上, FR-860 および通常 heparin は抗 F.Xa 活性 に依存したほぼ同等な抗血栓作用を示したが，FR-860 は通常 heparin に比し出血などの副作用の発現の可能 性は低く, FR-860 は臨床上透析や抗血栓療法などに有 用であると思われる.

謝辞 : 本研究を共に推進して頂きました当研究所の衣川 真弓噻に感謝致します.

\section{文献}

1) Willimann, P., Alig, A. and Binswanger, U.: Nephron 23, 191 (1979)

2) Swartz, R.D.: Nephron 28, 65 (1981)

3) Holm, H.A., Abildgaard, U., Kalvenes, S., Anderssen, N., Anker, E., Arnesen, K.E., Blikom, D. and Drivenes, A.: Acta Med. Scand. 215, 47 (1984)

4) Andersson, L.O., Barrowcliffe, T.W., Holmer, E., Johnson, E.A. and Söderström, G.: Thromb.
Res. 15, 531 (1979)

5) Holmer, E., Kurachi, K. and Söderström, G. : Biochem. J. 193, 395 (1981)

6) Holmer, E., Mattsson, G. and Nilsson, S.: Thromb. Res. 25, 475 (1982)

7) Garter, C., Kelton, J.G., Hirsh, J., Gerskus, A., Santos, A.V. and Gent, M.: Blood 59, 1239 (1982)

8) Hashimoto, N., Morita, T. and Iwanaga, S.: J. Biochem. 97, 1347 (1985)

9) Owen, W.G., Esmon, C.T. and Jackson, C.M.: J. Biol. Chem. 249, 594 (1974)

10) Morita, T. and Jackson, G.M.: J. Biol. Chem. 261, 4008 (1986)

11) 小林紀夫, 高田雅史, 田中 広, 権守日出海, 前川 正：血液と脈管 11，164（1980）

12) 内藤 惇, 平工誠治, 久我哲郎 : 応用薬理 27, 267 (1984)

13) Lockner, D., Bratt, G., Törnebohm, E. and Åberg, W.: Haemostasis 16, Supp. 2, 8 (1986)

14) Hamano, S., Komatsu, H., Ikeda, S., Takahashi, K., Oguma, Y. and Sakuragawa, N.: Thromb. Res. (印刷中)

15) Palm, M. and Mattson, C.: Thromb. Haemost. 58, 932 (1987)

16) Esquivel, C.O., Bergqvist, D., Björck, C.G. and Nilsson, B.: Thromb. Res. 28, 389 (1982)

17) Engelberg, H.: Dis. Chest. 42, 119 (1962)

18) Persson, E.: Acta Med. Scand. Supp. 724, 1 (1988) 


\begin{abstract}
Antithrombotic effects of low molecular weight heparin (FR-860) in rabbits. Shuichiro HAMANO, Hidetada KOMATSU, Shigeru IKEDA and Nobuo SAKURAGAWA* (Central Research Laboratories, Kissei Pharmaceutical Co., Ltd., Matsumoto 399, Japan, and *Department of Clinical Laboratory Medicine, Toyama Medical and Pharmaceutical University, Toyama 930-01, Japan). Folia pharmacol. japon. 94, 237 242 (1989)

Effects of low molecular weight heparin (FR-860) were investigated on the arterio-venous (A-V) shunt model and on the in vitro blood coagulation system compared to conventional unfractionated heparin (UF-heparin) in rabbits. In the A-V shunt model, FR-860 (12.5 $50 \mathrm{U} / \mathrm{kg}$, i.v.) and UF-heparin (25 and $50 \mathrm{U} / \mathrm{kg}$, i.v.) dose-related inhibited thrombotic formation in the tube of the $\mathrm{A}-\mathrm{V}$ shunt at $30 \mathrm{~min}$ after starting blood circulation. Both FR-860 and UF-heparin dose-relatedly increased the anti-F.Xa activity at 5 min after starting blood circulation. However, FR-860 showed weaker effects in a prolongation of the aPTT, PT and thrombin time than UF-heparin in the A-V shunt model. Neither FR-860 nor UF-heparin had any influence on platelet aggregation. FR-860 also had a weaker effect in the prolongation of the plasma recalcification time, aPTT and PT than UF-heparin in vitro. FR-860 showed equipotent efficacy on the anti-F.Xa activity and had weak antithrombin activity compared to that of UF-heparin in vitro. These results suggest that the antithrombotic effect of FR-860 mainly depends on its anti-F.Xa activity but not on the antithrombin activity. Therefore, FR-860 is more efficient and lower in bleeding risk than UF-heparin in hemodialysis and thrombotic disorders.
\end{abstract}

